\title{
Soviet Russians under Nazi Occupation: Fragile Loyalties in World War II
}

\author{
Johannes Due Enstad \\ Cambridge: Cambridge University Press 2018 \\ 272 sider. ISBN 9781108421263
}

Anmeldt af Karl Christian Lammers [lektor emeritus, Saxo-Instituttet, Københavns Universitet, lammers@hum.ku.dk]

Det nazistiske Tysklands angreb på og invasion af Sovjetunionen fra juni 1941 førte til erobring af enorme landområder, og som det er bekendt kom den tyske civile og militære forvaltning til at belaste det besatte territorium enormt hvad angår ødelæggelser og tab af menneskeliv. Den eksisterende historiske forskning har undersøgt og dokumenteret de alvorlige konsekvenser som den tyske besættelse fik for de vestlige ikke-russiske områder som Ukraine, Hviderusland og de tre baltiske stater og for de mennesker der levede her. Men indtil nu har meget lidt været kendt med hensyn til situationen i de besatte russiske oblaster (administrative distrikter) hvor der overvejende boede indfødte russere. I en godt researchet og dokumenteret undersøgelse har den norske historiker Johannes Due Enstad med den foreliggende bog kastet nyt og dybtgående lys over de nordvestlige oblaster, altså stort set området beliggende mellem Leningrad og Moskva, og dermed har han udfyldt et hul i den historiske udforskning af den tyske krig og besættelsespolitik på østfronten.

Det nordvestlige område var først og fremmest beboet af en bondebefolkning, og Enstads undersøgelse muliggør derfor på russisk kildemateriale et indblik i de erfaringer som den indfødte russiske landbefolkning gjorde med de tyske besættere og deres forvaltning af området. Ifølge Enstad forbandt formentlig et flertal af bønderne tyskernes invasion med håbet om et bedre liv der var fri for kollektiver, og om et nyt regime. Samtidig tillader hans undersøgelse også at drage nogle slutninger hvad angår stalinismens legitimitet og loyaliteten over for det stalinistiske styre i landlige områder. Fra de fleste russere savnede Stalins regime folkelig tilslutning.

Det er Enstads intention at forsøge at sætte spørgsmålstegn ved den alment hævdede opfattelse at den russiske del af befolkningen i modsætning til befolkningerne i de ikke-russiske grænseområder gjorde omfattende og patriotisk modstand mod de tyske besættere. Det lykkes det at vise for det nordvestlige område. På grundlag 
af et omfattende sovjetisk og tysk kildemateriale kan forfatteren eftervise at de tyske besættere i de områder der stod under tysk militær forvaltning, for det meste blev hilst velkommen af den landlige befolkning. Det hænger først og fremmest sammen med at den tyske besættelse førte til befrielse fra det barske bolsjevikiske styre, herunder ikke mindst fra den tvungne og forhadte kollektivisering af store og mindre landbrug. Opløsningen af kollektiverne og legaliseringen af opløsningen bidrog til at skabe sympati for tyskerne, og for mange bønder førte privatiseringen af brugene til bedre materielle forhold. Det fremgår af undersøgelsen af livet i de afkollektiviserede landsbyer. Til gengæld blev landbefolkningen pålagt andre byrder af tyskerne som for eksempel tvangsarbejde.

End ikke den nazistiske terror mod og forfølgelse af jøder, sigøjnere og andre bortset fra sovjetiske krigsfanger - synes at have rystet det generelle (positive) politiske forhold til tyskerne. Forfatteren viser at frem til begyndelsen af den tyske hærs tilbagetrækning i 1943 var den landlige befolkning mere tilbøjelig til at støtte den tyske magt end at støtte den sovjetiske regering eller partisanbevægelsen. Efter Enstads mening gjorde den det ud fra materielle interesser, politiske og patriotiske følelser, og i forfølgelsen af hvad han kalder kalkuleret pragmatisme, det vil sige en strategi der bøjede sig for den stærkere magt og som betød skiftende loyalitet når det var nødvendigt. Det førte med tysk billigelse endda til en slags religiøs vækkelse i de besatte områder. På den måde kan de sovjetiske russeres erfaringer med besættelse og fremmed styre bidrage til også at kaste nyt lys på forholdet mellem regime og folk i det stalinistiske Rusland.

Enstads dygtigt og omhyggeligt gennemførte undersøgelse af de hverdagserfaringer som den primært russiske landbefolkning gjorde under den tyske besættelse gør det muligt for den historiske forskning at differentiere den store fortælling om den patriotiske russiske krig mod de tyske invasorer. "Den store fædrelandskrig" om et samlet sovjetisk folks modstand mod tyskerne var i visse henseender en myte. Det virkelige billede af de indfødte russeres deltagelse og loyalitet var meget mere komplekst som følge af den blandede holdning hos den landlige befolkning til det stalinistiske regime og styre. Dette illustrerer hvor forhadt det bolsjevikiske styre var på landet. 